\author{
V. Tkach ${ }^{1,2}$, S. C. de Oliveira ${ }^{2}$, R. Ojani ${ }^{3}$, \\ O. V. Elenich ${ }^{1}$, P. I. Yagodynets ${ }^{1}$ \\ ${ }^{1}$ Chernivtsi National University named Fedkovych, Ukraine \\ ${ }^{2}$ Federal University of Mato-Gross-do-Sul, Brazil \\ ${ }^{3}$ University of Mazandaran, Islamic Republic of Iran \\ E-mail: nightwatcher2401@gmail.com
}

\title{
Mathematical description of «polythiophene paradox» for potentiostatic electropolymerization of electrochemically modified thiophenes
}

The phenomenon of "polythiophene paradox" for insoluble polythiophenes based on electrochemically modified monomers has been described theoretically. The corresponding mathematical model was examined using linear theory of stability and bifurcation analysis. Stability conditions of steady state, monotonic and oscillatory instabilities have also been obtained.

Key words: polythiophene; electrochemical modification; positively paradox; electropolymerization; stable steady state.

Received: 08.10.2016; accepted: 22.10.2016; published: 30.12.2016.

В. В. Ткач ${ }^{1,2}$, С. С. де Оливейра ${ }^{2}$, Р. Ожани ${ }^{3}$, О. В. Еленич ${ }^{1}$ П. И. Ягодинец

${ }^{1}$ Черновицкий национальный университет им. Ю. Федьковича, Украина ${ }^{2}$ Федеральный университет штата Мату-Гроссу-ду-Сул, Бразилия

${ }^{3}$ университет Мазендерана, Исламская Республика Иран E-mail: nightwatcher2401@gmail.com

\section{Математическое описание «политиофенового парадокса» для потенциостатической электрополимеризации электрохимически модифицированных тиофенов}

Явление «политиофенового парадокса» для нерастворимых политиофенов на основе электрохимически модифицированных мономеров было описано теоретически. Соответствующая математическая модель была рассмотрена с помощью линейной теории устойчивости и бифуркационного анализа. Условия устойчивости стационарного состояния, монотонной и автоколебательной неустойчивостей также были получены.

Ключевые слова: политиофен; электрохимическая модификации; политиофеновый парадокс; электрополимеризация; устойчивое стационарное состояние.

Поступило: 08.10.2016; принято: 22.10.2016; опубликовано: 30.12.2016.

(c) Tkach V., de Oliveira S. C., Ojani R., Elenich 0. V., Yagodynets P. I., 2016 
Polythiophene (PT) is one of the most used conductive polymers (PP) of heterocyclic compounds, since the potential polymerization of its monomer is lower than that of unsubstituted benzene, and its stability in different environments is higher than that of pyrrole and furan. [1-8]. It is also worth mentioning that PT was the first conducting polymer, commercially used in electrostatic brushes produced by the company "Xerox".

In the synthesis of the PP the choice of the monomer is guided by the properties of the resulting polymer and sometimes it is more convenient to obtain monomers by electrochemical methods than chemically [9-12]. Moreover, some electrochemical transformations of organic compounds do not have the purely chemical analogies.

PT can be obtained either chemically or electrochemically and the latter method has some advantages over the first - for example, the best conductivity of the polymer and coplanarity between the monomer fragments in it. However, the electrochemically synthesized polythiophene may undergo partial overoxidation due to the fact that its potential of overoxidation may be equal or lower than the potential of polymerization of the corresponding monomer. This phenomenon discovered in 1989 was named "polythiophene paradox" and is manifested in the appearance of oxygen-containing functional groups and the decrease in conductivity in the polymer, due to changes in the configu-

\section{The system and its model}

With the purpose of the mathematical description of potentiostatic $\left(\mathrm{U}>\mathrm{U}_{\bmod }>\right.$ $>\mathrm{U}_{\mathrm{pol}}>\mathrm{U}_{\mathrm{ov}}$ ) electropolymerization of thiophene, electrochemically modified with the help of the substances present ration of the conjugated system [13-14]. Further researches showed that the "polythiophene paradox" is also possible for some of polypyrroles [15-17], making the explanation of this phenomenon is important not only to determine the exact mechanism of electropolymerization of thiophenes, but in general for the synthesis of polymers of five-membered heterocyclic compounds. This phenomenon is manifested among other things and in electrochemical instabilities - fluctuations in current or potential or the multiplicity of the stationary states [15-17].

The phenomenon of "polythiophene paradox" has been described by many experimental methods and electrochemical instabilities basically obtained a phenomenological interpretation. The main disadvantage of this explanation is that despite the fact that it can be derived from the point of view of purely logical reflections, it is not based on the solid theoretical basis, which can only be given through development and analysis of mathematical models able to adequately describe the processes in the system.

We have attempted to describe the processes of overoxidation (including "polythiophene paradox") for polymers of monomers present in the solution [18-20]. Now the aim of our work is to describe the same phenomenon for the monomers, obtained electrochemically, the study of the behavior of the given process and comparison with the general case "polythiophene paradox".

in solution in excess, we introduce two variables:

- $\Theta_{1}$ - the degree of coverage of the electrode by modified monomer; 
- $\Theta_{2}$ - the degree of coverage of the electrode by nonoveroxidation polythiophene.

To simplify the model we assume that non-modified monomer at the initial moment of the reaction covers the surface of the anode completely $\left(\Theta_{0}^{t=0}=1\right)$.

The modified monomer is obtained by electrochemical oxidation of the starting monomer and then electropolymerizes. In turn, the polymer overoxidizes at the same time with their own synthesis. Thus, the balance equations for their concentrations will be written as:

$$
\begin{aligned}
& \frac{d \theta_{1}}{d t}=\frac{1}{\Gamma_{\max }}\left(r_{1}-r_{2}\right) \\
& \frac{d \theta_{2}}{d t}=\frac{1}{G_{\max }}\left(r_{2}-r_{3}\right)
\end{aligned}
$$

where $r_{1}, r_{2}$ and $r_{3}$ are speeds of modification, polymerization and overoxidation which can be described as:

$$
\begin{aligned}
& r_{1}=k_{1}\left(1-\theta_{1}-\theta_{2}\right) \exp \left(-\frac{z_{1} F \varphi_{0}}{R T}\right), \\
& r_{2}=k_{2} \theta_{1}^{\zeta} f\left(\llbracket \theta_{2}\right) \exp \rrbracket\left(-\frac{z_{2} F \varphi_{0}}{R T}\right) \\
& r_{3}=k_{3} \theta_{2} \exp \left(-\frac{z_{3} F \varphi_{0}}{R T}\right)
\end{aligned}
$$

where $k_{1}, k_{2}, k_{3}$ are the rate constants of the corresponding reactions, $z_{1}, z_{2}, z_{3}$ is the number of electrons transferred in each of them, $\varphi 0$ is the potential jump relative to the zero charge potential, $\xi$ is the reaction order of electropolymerization on the monomer, $f\left(\theta_{2}\right)$ is a function of the possible autocatalytic growth of the polymer chain, rising to the order of reaction with respect to the polymer. Autocatalytic growth of the chain occurs due to the acceleration of electrochemical reaction at transition from monomer through oligomers to the polymer.

Mathematically equations remind of equations (2-3) of general model for polythiophene paradox for the case of the presence of monomer in solution [19] that shows the similarity of the systems. However, due to the fact that in this case the process occurs completely on the surface and also in view of the presence of the greater number of electrochemical steps the system behavior will be slightly different from the general case that will be described and discussed below.

\section{Results and discussion}

To analyze the behavior of the system with "polythiophene paradox" under electropolymerization of electrochemically generated polymers we analyze the system of differential equations (1-2) using linear stability theory. Functional Jacobian matrix whose elements are calculated for the stationary state can be shown as:

$$
\left(\begin{array}{ll}
a_{11} & a_{12} \\
a_{21} & a_{22}
\end{array}\right),
$$

$$
\begin{aligned}
a_{11} & =\frac{1}{\Gamma_{\max }}\left(a_{1} r_{1}-\frac{r_{1}}{\left(1-\theta_{1}-\theta_{2}\right)}-\right. \\
& \left.-r_{2} f^{\prime}\left(\theta_{2}\right)\left(a_{2} r_{2}-\xi \frac{r_{2}}{\theta_{1}}\right)\right) \\
a_{12}= & \frac{1}{\Gamma_{\max }}\left(b_{1} r_{1}-\frac{r_{1}}{\left(1-\theta_{1}-\theta_{2}\right)}-b_{2} r_{2}\right) \\
a_{21} & =\frac{1}{G_{\max }}\left(a_{2} r_{2}+\zeta \frac{r_{2}}{\theta_{1}}-a_{3} r_{3}\right)
\end{aligned}
$$


$a_{22}=\frac{1}{G_{\max }}\left(r_{2} f^{\prime}\left(\theta_{2}\right)\left(b_{2} r_{2}-\xi \frac{r_{2}}{\theta_{1}}\right)-b_{3} r_{3}-\frac{r_{3}}{\theta_{2}}\right)$

Here $\mathrm{a}_{\mathrm{x}}$ and $\mathrm{b}_{\mathrm{x}}$ are parameters describing the effect of the electrochemical reactions in the electric double layer (EDL).

The necessary conditions for the oscillatory behavior described by Andronov-Hopf bifurcation are $\operatorname{Tr} \mathrm{J}=0$, Det $\mathrm{J}>0$ (simultaneously); where $\operatorname{Tr} \mathrm{J}=a_{11}$ $+a_{22}$ is the trace of the Jacobian matrix and Det $J$ is its determinant. Since the second condition is satisfied in most cases, the first one is the main at calculation which for this system are written as:

$$
\begin{gathered}
\frac{1}{\Gamma_{\max }}\left(a_{1} r_{1}-\frac{r_{1}}{\left(1-\theta_{1}-\theta_{2}\right)}-\right. \\
\left.-r_{2} f^{\prime}\left(\theta_{2}\right)\left(a_{2} r_{2}-\xi \frac{r_{2}}{\theta_{1}}\right)\right) \\
\frac{1}{G_{\max }}\left(r_{2} f^{\prime}\left(\theta_{2}\right)\left(b_{2} r_{2}-\xi \frac{r_{2}}{\theta_{1}}\right)-\right. \\
\left.-b_{3} r_{3}-\frac{r_{3}}{\theta_{2}}\right)=0 .
\end{gathered}
$$

This condition can be satisfied only in case of presence in the main diagonal of the Jacobian matrix of positive elements, describing the positive feedback. You can see that the elements $a_{x} r_{x}$ and $b_{x} r_{x}$, where $\mathrm{x}$ is the phase number can be positive (or negative under the sign minus), depending on the impact of the electrochemical stages of the reaction on the capacity of DES and the strength of oxidising substances as reducing agents. This factor is common to all systems with electropolymerization [18-20].

The second factor responsible for the oscillatory behavior can be autocatalytic chain growth, the impact of which is described by the positivity of the elements containing the derivative of the function $f$ that describes this growth.

Thus, in this system self-oscillatory behavior is caused by two factors electrochemical and autocatalytic. There are temporal dissipative structures in this system the existence of which maintained by steady "supply" of the initial monomer and by the excess of the modifying substance in the solution (input entropy) and by the overoxidation of the polymer formed by (output entropy). The factor of interaction of particles on the surface of the electrode by adsortion - desorption, which is the reason of self-oscillations in such systems [18-20] does not apply here owing to the purely superficial nature of the process.

For two-dimensional systems the conditions of stability of stationary states are described as: $\operatorname{Tr} \mathrm{J}<0$, Det $\mathrm{J}>0$. Herewith the latter condition is main. For analysis of the determinant of the Jacobian matrix without cumbersome expressions we introduce new variables so that the determinant of a matrix was written as:

$$
\frac{1}{\Gamma_{\max 1} G_{\max 1}}\left|\begin{array}{ll}
R 1-R 2 & X 1-X 2 \\
R 2-R 3 & X 2-X 3
\end{array}\right| .
$$

Opening the straight brackets and solving the inequality Det $\mathrm{J}>0$ relative to $\mathrm{R} 1$, we obtain the condition of stability of stationary state for the system in the form:

$$
R_{1}>\frac{R_{2}\left(X_{3}-X_{1}\right)-R_{3}\left(X_{1}-X_{2}\right)}{X_{2}-X_{3}} .
$$

This inequality is satisfied, in the case of the growth of effects of modification of the monomer and overoxidation of the corresponding polymer (increase $\mathrm{R}_{1}$ and $\mathrm{R}_{3}$ ) on DES and the fall of the effects of electropolymerization on it (drop $R_{2}$ ). Also the stability of the stationary state is determined by the stability of the polymer 
$\left(\mathrm{X}_{2}>\mathrm{X}_{3}\right)$. The process is controlled by adsorption of unmodified monomer as in the similar case of electrooxidation of procarbazine [21-22].

The critical value of the parameter $R_{1}$ which is on topological limit of stability of stationary state corresponds to the multiplicity of steady states, the condition of which is:

$$
R_{1}=\frac{R_{2}\left(X_{3}-X_{1}\right)-R_{3}\left(X_{1}-X_{2}\right)}{X_{2}-X_{3}} .
$$

It appears by $\mathrm{N}$-shaped plot of voltamperogramme and explains the equality of the stabilizing and destabilizing influences of the electrochemical processes at DEL.

The reaction in galvanostatic and potentiometric modes is described by

\section{Conclusion}

From the analysis of the system with polythiophene paradox under electropolymerization of electrosynthesized monomers, we can conclude that:

- As for all similar systems with "polythiophene paradox" the temporal dissipative structures present in this system, the existence of which is maintained by steady "supply" of the initial monomer and by an excess of the modifying substance in the solution and by overoxidation of the

- The stability of the stationary state is determined by the distribution of the efformed polymer.

system based on the described above, while the variable introduces in the SDR that describes the change in charge density of the anode. The behavior of such system is more complex and will be described in future works.

Effect of $\mathrm{pH}$ is an important factor in the behavior of the system, because the process of electropolymerization and the process of overoxidation are highly dependent on $\mathrm{pH}$. This system describes the electrosynthesis of polythiophene at neutral $\mathrm{pH}$. In the case of more acidic $\mathrm{pH}$ third variable introduces in the above described DES that describes the behavior of protons. Addition to the above factors it can also be responsible for the appearance of electrochemical instabilities in this system.

fects of electrochemical processes on the DEL so that the polymer remained stable. The process is controlled by the adsorption of initial monomer.

- In case of equality of stabilizing and destabilizing influences in DEL, the monotonic instability, manifested in the multiplicity of the stationary states realizes.

- The oscillatory instability in this system can be caused by the action of the factor of influence of electrochemical processes on the DEL and autocatalytic factors.

\section{In Russian}

Политиофен (ПТ) является одним из наиболее используемых проводящих полимеров (ПП) гетероциклических соединений, ибо потенциал полимеризации его мономера ниже, чем для незамещенного бензола, а устой- чивость в различных средах выше, чем у пиррола и фурана. [1-8]. Стоит также упомянуть, что ПТ был первым проводящим полимером, получившим коммерческое применение в электро- 
статических щетках производства компании Xerox.

При синтезе ПП при выборе мономера руководствуются свойствами результирующего полимера и иногда получать мономеры по электрохимическим методикам более удобно, чем химически [9-12]. При этом некоторые электрохимические превращения органических веществ не имеют чисто химических аналогий.

ПТ можно получить как химически, так и электрохимически, и последний метод имеет некоторые преимущества перед первым - к примеру, лучшая проводимость полимера и компланарность между мономерными фрагментами в нем. Однако электрохимически синтезированный политиофен может подвергаться частичному переокислению ввиду того, что его потенциал переокисления может быть равным потенциалу полимеризации соответствующего мономера. Данное явление, открытое в 1989 году, получило название «политиофенового парадокса» и проявляется в появлении в полимере кислородсодержащих функциональных групп и снижении проводимости, ввиду изменения конфигурации сопряженной системы [13-14]. Дальнейшие исследования показали, что «политиофеновый парадокс» возможен также для некоторых полипирролов [15-17], что делает объяснение данного феномена важным не только для определения точного механизма электрополимеризации тиофенов, но и вообще для синтеза полимеров пятичленных гетероциклических соединений. Это явление проявляется, среди прочего, и в электрохимических неустойчивостях - колебаниях тока или потенциала или множественности стационарных состояний [15-17].

Явление «политиофенового парадокса» было описано множеством экспериментальных методов, и электрохимические неустойчивости в основном получали феноменологическую интерпретацию. Главным недостатком такого объяснения является то, что, несмотря на то, что его можно вывести с точки зрения сугубо логических размышлений, оно не зиждется на прочном теоретическом основании, которое может быть дано только с помощью разработки и анализа математической модели, способной адекватно описать процессы в системе.

Мы уже предприняли попытку описать процессы переокисления (в том числе «политиофеновый парадокс») для полимеров мономеров, присутствующих в растворе [18-20]. Сейчас же целью нашей работы является описание того же явления для мономеров, полученных электрохимически, изучение поведения данного процесса и его сравнение с общим случаем «политиофенового парадокса».

щего в растворе в избытке, мы вводим две переменные:

- $\Theta_{1}$ - степень покрытия электрода модифицированным мономером;

- $\Theta_{2}$ - степень покрытия электрода непереокисленным политиофеном. 
С целью упрощения модели мы предполагаем, что немодифицированный мономер в начальный момент реакции полностью покрывает поверхность анода $\left(\Theta_{0}^{t=0}=1\right)$.

Модифицированный мономер получается электрохимическим окислением начального мономера, а затем электрополимеризируется. В свою очередь, полимер переокисляется одновременно с собственным синтезом. Таким образом, балансовые уравнения для их концентрации запишутся как:

$$
\begin{aligned}
& \frac{d \theta_{1}}{d t}=\frac{1}{\Gamma_{\max }}\left(r_{1}-r_{2}\right) \\
& \frac{d \theta_{2}}{d t}=\frac{1}{G_{\max }}\left(r_{2}-r_{3}\right),
\end{aligned}
$$

где $r_{1}, r_{2}$ и $r_{3}$ - скорости модификации, полимеризации и переокисления, которые могут быть описаны как:

$$
\begin{aligned}
& r_{1}=k_{1}\left(1-\theta_{1}-\theta_{2}\right) \exp \left(-\frac{z_{1} F \varphi_{0}}{R T}\right), \\
& r_{2}=k_{2} \theta_{1}^{\zeta} f\left(\llbracket \theta_{2}\right) \exp \rrbracket\left(-\frac{z_{2} F \varphi_{0}}{R T}\right) \\
& r_{3}=k_{3} \theta_{2} \exp \left(-\frac{z_{3} F \varphi_{0}}{R T}\right)
\end{aligned}
$$

\section{Результаты и обсуждения}

С целью анализа поведения системы с «политиофеновым парадоксом» при электрополимеризации электрохимически генерированных полимеров, мы анализируем систему дифференциальных уравнений (1-2) с использованием линейной теории устойчивости. Функциональная матрица Якоби, элементы которой вычислены для стационарного состояния, может быть показана как: где $k_{1}, k_{2}, k_{3}-$ константы скоростей соответствующих реакций, $z_{1}, z_{2}, z_{3}-$ количество электронов, переданных в каждой из них, $\varphi_{0}$ - скачок потенциала относительно потенциала нулевого заряда, $\xi$ - порядок реакции электрополимеризации по мономеру, $f\left(\theta_{2}\right)$ - функция возможного автокаталитического роста полимерной цепи, восходящая к порядку реакции по полимеру. Автокаталитический рост цепи возникает ввиду ускорения электрохимической реакции при переходе от мономера через олигомеры к полимеру.

Математически уравнения (1-2) напоминают уравнения (2-3) общей модели для политиофенового парадокса для случая присутствия мономера в растворе [19], что отображает подобность систем. Однако в связи с тем, что в данном случае процесс полностью происходит на поверхности, а также ввиду присутствия бо́льшего количества электрохимических стадий, поведение данной системы будет несколько отличаться от общего случая, что будет описано и обсуждено ниже.

$$
\left(\begin{array}{ll}
a_{11} & a_{12} \\
a_{21} & a_{22}
\end{array}\right),
$$

где

$$
\begin{gathered}
a_{11}=\frac{1}{\Gamma_{\max }}\left(a_{1} r_{1}-\frac{r_{1}}{\left(1-\theta_{1}-\theta_{2}\right)}-\right. \\
\left.-r_{2} f^{\prime}\left(\theta_{2}\right)\left(a_{2} r_{2}-\xi \frac{r_{2}}{\theta_{1}}\right)\right) \\
a_{12}=\frac{1}{\Gamma_{\max }}\left(b_{1} r_{1}-\frac{r_{1}}{\left(1-\theta_{1}-\theta_{2}\right)}-b_{2} r_{2}\right)
\end{gathered}
$$




$$
a_{21}=\frac{1}{G_{\max }}\left(a_{2} r_{2}+\zeta \frac{r_{2}}{\theta_{1}}-a_{3} r_{3}\right)
$$

Здесь $a_{x}$ и $b_{x}$ - параметры, описывающие влияние электрохимических реакций на двойной электрический слой (ДЭС).

Необходимые условия для автоколебательного поведения, описываемого бифуркацией Андронова - Хопфа, $\operatorname{Tr} \mathrm{J}=0$, Det $\mathrm{J}>0$ (одновременно), где $\operatorname{Tr} \mathrm{J}=a_{11}+a_{22}-$ след матрицы Якоби, a Det J - eе определитель. Поскольку второе условие удовлетворяется в большинстве случаев, главным в расчете является первое, которое для данной системы запишется как:

$$
\begin{gathered}
\frac{1}{\Gamma_{\max }}\left(a_{1} r_{1}-\frac{r_{1}}{\left(1-\theta_{1}-\theta_{2}\right)}-\right. \\
\left.-r_{2} f^{\prime}\left(\theta_{2}\right)\left(a_{2} r_{2}-\xi \frac{r_{2}}{\theta_{1}}\right)\right) \\
\frac{1}{G_{\max }}\left(r_{2} f^{\prime}\left(\theta_{2}\right)\left(b_{2} r_{2}-\xi \frac{r_{2}}{\theta_{1}}\right)-\right. \\
\left.-b_{3} r_{3}-\frac{r_{3}}{\theta_{2}}\right)=0 .
\end{gathered}
$$

Данное условие может быть удовлетворено только в случае присутствия в главной диагонали матрицы Якоби положительных элементов, описывающих положительную обратную связь. Можно увидеть, что элементы $a_{x} r_{x}$ и $b_{x} r_{x}$, где $x$ - номер стадии, могут быть положительными (или отрицательными под знаком минус), в зависимости от влияния на емкость ДЭС электрохимических стадий реакции и от силы окисляющихся веществ как восстановителей. Данный фактор общий для всех систем с электрополимеризацией [18-20].

Вторым фактором, ответственным за автоколебательное поведение, мо- жет быть автокаталитический рост цепи, влияние которого описывается положительностью элементов, содержащих производную функции $f$, описывающей этот рост.

Таким образом, в данной системе автоколебательное поведение вызывается действием двух факторов - электрохимического и автокаталитического. В системе присутствуют временные диссипативные структуры, существование которых поддерживается устойчивым «запасом» начального мономера и избытком модифицирующего вещества в растворе (вход энтропии) и переокислением образованного полимера (выход энтропии). Фактор взаимодействия частичек на поверхности электрода при адсорбции - десорбции, который является причиной автоколебаний в других подобных системах [18-20] здесь не действует ввиду чисто поверхностной природы процесса.

Для двуразмерных систем условия устойчивости стационарного состояния описываются как: $\operatorname{Tr} \mathrm{J}<0$, Det J $>0$. При этом последнее условие считается главным. С целью анализа определителя матрицы Якоби без громоздких выражений мы вводим новые переменные таким образом, чтобы определитель матрицы записался как:

$$
\frac{1}{\Gamma_{\max 1} G_{\max 1}}\left|\begin{array}{ll}
R 1-R 2 & X 1-X 2 \\
R 2-R 3 & X 2-X 3
\end{array}\right| .
$$

Раскрывая прямые скобки и решая неравенство Det J > 0 относительно $R_{1}$, мы получаем условие устойчивости стационарного состояния для данной системы в виде:

$$
R_{1}>\frac{R_{2}\left(X_{3}-X_{1}\right)-R_{3}\left(X_{1}-X_{2}\right)}{X_{2}-X_{3}} .
$$


Данное неравенство удовлетворяется в случае роста влияний на ДЭС модификации мономера и переокисления соответствующего полимера (рост $R_{1}$ и $R_{3}$ ), а также падения влияния на него электрополимеризации (падение $R_{2}$ ). Также устойчивость стационарного состояния определяется устойчивостью полимера $\left(X_{2}>X_{3}\right)$. Процесс при этом контролируется адсобцией немодифицированного мономера, как и в аналогичном случае электроокисления прокарбазина [21-22].

Критическое значение параметра $R_{1}$, находящееся на топологическом пределе устойчивости стационарного состояния, соответствует множественности стационарных состояний, условием которого является:

$$
R_{1}=\frac{R_{2}\left(X_{3}-X_{1}\right)-R_{3}\left(X_{1}-X_{2}\right)}{X_{2}-X_{3}} .
$$

Оно отображается N-образным участком вольтамперограммы и объясняется равенством стабилизирующих и дестабилизирующих влияний электрохимических процессов на ДЭС.

Реакиия в гальваностатическом u потенциодинамическом режимах описывается системой, базирующейся на описанной выше, при этом в СДР вводится переменная, описывающая изменение плотности заряда анода. Поведение такой системы является еще более сложным и будет описано нами в следующих работах.

Влияние рН является важным фактором поведения данной системы, ибо как процесс электрополимеризации, так и процесс переокисления сильно зависят от рН. Данная система описывает электросинтез политиофена при нейтральном рН. В случае более кислых $\mathrm{pH}$ в описанную выше СДР вводится третья переменная, описывающая поведение протонов. Оно помимо указанных факторов также может быть ответственным за появление электрохимических неустойчивостей в системе.

\section{Выводы}

Из анализа системы с политиофеновым парадоксом при электрополимеризации электросинтезированных мономеров можно сделать выводы о том, что:

- Как и для всех аналогичных систем с «политиофеновым парадоксом», в данной системе присутствуют временные диссипативные структуры, существование которых поддерживается устойчивым «запасом» начального мономера и избытком модифицирующего вещества в растворе и переокислением образованного полимера.

- Устойчивость стационарного состояния определяется таким распре- делением влияний электрохимических процессов на ДЭС, чтобы полимер при этом оставался устойчивым. Процесс контролируется адсорбцией начального мономера.

- В случае равенства стабилизирующих и дестабилизирующих влияний в ДЭС, реализуется монотонная неустойчивость, проявляющаяся во множественности стационарных состояний.

- Автоколебательная неустойчивость в данной системе может быть вызвана действием фактора влияния электрохимических процессов на ДЭС и автокаталитических факторов. 


\section{Bibliography}

1. Yamamoto T. Molecular assembly and properties of polythiophenes. NPG Asia Materials. 2010;2(2):54-60. DOI: 10.1038/asiamat.2010.37.

2. Shirakawa $H$. The discovery of polyacetylene film: The dawning of an era of conducting polymers(Nobel lecture). Angewandte Chemie - International Edition. 2001;40(14):2575-2580.

3. MacDiarmid A. G. "Synthetic metals": A novel role for organic polymers (Nobel lecture). Angewandte Chemie - International Edition. 2001;40(14):2581-2590. DOI: 10.1002/1521-3773(20010716)40:14<2581::AID-ANIE2581>3.0.CO;2-2.

4. Heeger A. J. Semiconducting and metallic polymers: The fourth generation of polymeric materials (nobel lecture). Angewandte Chemie - International Edition. 2001;40(14):2591-2611. DOI: 10.1002/1521-3773(20010716)40:14<2591::AIDANIE2591>3.0.CO;2-0.

5. McCullough R. D. The chemistry of conducting polythiophenes. Advanced Materials. 1998;10(2):93-116.

6. Yoshida J. I., Kataoka K., Horcajada R., Nagaki A. Modern strategies in electroorganic synthesis. Chem. Rev. 2008;108(7):2265-2299. DOI: 10.1021/cr0680843.

7. Groenendaal L., Jonas F., Freitag D., Pielartzik H., Reynolds J. R. Poly(3,4-ethylenedioxythiophene) and its derivatives: past, present, and future. Advanced Materials. 2000;12(7):481-494. DOI: 10.1002/(SICI)1521-4095(200004)12:7<481::AIDADMA481>3.0.CO;2-C.

8. Meijer E. J., Leeuw De D.M., Setayesh S., Van Veenendaal E., Huisman B.-H., Blom P.W.M., Hummelen J.-C., Scherf U., Klapwijk T.M. Solution-processed ambipolar organic field-effect transistors and inverters. Nature Materials. 2003:2(10):678-682. DOI: $10.1038 /$ nmat978.

9. Yadhav K. G. Synthesis of monomers for new conjugated polymers, M.Sc. Thesis, University of Massachusetts, 2012.

10. Sharma L. K, Kumar S., Singh S., Singh R. K. P. Electrochemical synthesis of 5-substituted-2-amino (substituted amino)-1,3,4-oxadiazoles at the platinum electrode. Russ.J Electrochem. 2010;46(1):34-40. DOI: 10.1134/S1023193510010040.

11. Singh S., Kumar S., Sharma L. K., Singh R. K. P. A novel electroorganic synthesis of some 2-amino-5-substituted-1,3,4- oxadiazoles at the platinum electrode. J. Indian Chem. Soc. 2009;86(7):734-738.

12. Gütz C., Klöckner B., Waldvogel S. Electrochemical Screening for Electroorganic Synthesis. Organic Process Research and Development. 2016;20(1):26-32. DOI: 10.1021/acs.oprd.5b00377.

13. Roncali J. Conjugated poly(thiophenes): Synthesis, functionalization, and applications. Chem. Rev. 1992;92(4):711-738.

14. Krische B., Zagorska M. The polythiophene paradox. Synthetic Metals. 1989;28 (1-2):263-268. DOI: 10.1016/0379-6779(89)90531-6.

15. Aoki K., Mukoyama I., Chen J. Competition between polymerization and dissolution of poly(3-methylthiophene) films. Russ. J. Electrochem. 2004;40(3):280-285. DOI: 10.1023/B:RUEL.0000019665.59805.4c. 
16. Mostany J., Scharifker B. R. Direct microcalorimetric measurement of doping and overoxidation processes in polypyrrole. Electrochim. Acta. 1997;42(2):291-301.

17. Mostany J., Scharifker B. R. Impedance spectroscopy of undoped, doped and overoxidized polypyrrole films. Synthetic Metals. 1997;87(3):179-185.

18. Tkach V., Nechyporuk V., Yagodynets P. Descripción matemática de la síntesis electroquímica de polímeros conductores en la presencia de surfactants. Avances en Química. 2013;8(1):9-15.

19. Tkach V. V., NechyporukV. V., Yagodynets' P. I. Georgia Chem. J. 2011;11:387.

20. Tkach V. V., Nechyporuk V. V., Yagodynets' P. I. Quím. Bras. 2013;7:67.

21. Tkach V., Oliveira de S. C., Maia G., Guenther Soares B., Ojani R., Yagodynets P. I. The mathematical description of the electrosynthesis of composites of oxy-hydroxycompounds of cobalt with overoxidized polypyrrole. Chim. Techno Acta. 2016;3(1):85.

22. Oliveira S. C. B., Mendes C. H. S., Filho F. F. S., Queiroz N. L., Nascimento J. A. M., Nascimento V. B. Electrochemical oxidation mechanism of procarbazine at glassy carbon electrode. J. Electroanal. Chem. 2015;746:51-56.

\section{Cite this article as (как цитировать эту статью):}

V. Tkach, S. C. de Oliveira, R. Ojani, O. V. Elenich, P. I. Yagodynets. Mathematical description of "polythiophene paradox" for potentiostatic electropolymerization of electrochemically modified thiophenes. Chimica Techno Acta. 2016;3(4):278-288. 